\title{
"Administering Justice in a Leper Hospital
}

\author{
G. A. R.
}

A Leper Hospital differs from other hospitals in a number of ways. First of all a large number of the patients are able-bodied and they could if they found the idea attractive chase the Medical Superintendent and his tiny staff abruptly and humiliatingly off the premises. There are nearly two thousand of them. So that a situation might (in theory) arise where one would find exactly two thousand reasons for the belief that one minute more spent in the Settlement would be about five minutes too long.

A second difference is that the inhabitants of Sungei Buloh are segregated lepers. Now that makes quite a difference on their outlook. Most of us keep good-or as good as we are-through fear of the law and through pressure of our respectable environment. In other words we keep out of trouble for fear of the consequences, and also because we have got into the rut of being good, like everybody else, and are scared of what people would say. You picture the O.C.P.D.s with their enormous khaki topis on, coming down on you like a horde of evil brown-shirts, and all the dreadful machinery of Court.

But for a patient in a leper hospital these deterrents do not exist. He has been cut off from all his associates and has ceased to care what they think. He has lost his respect for the law-the law can't do anything worse to him than nature has already done.

It will readily be seen then that justice has to be modified a little in a Leper Hospital and that the Medical Superintendent besides being a doctor has to be Lord of the High Justice, the Middle and the Low. That is, if the patients are not to be run haywire all over the place.

We have a prison of course. But prison with us is not a reformatory nor is it a punishment; it is a disgrace and the patients are constantly taught so. This means that putting a patient in prison for one hour is just as good as putting him in for a whole day-saves one a lot of trouble.

Justice is different in other ways too. Some sentences are much milder than they would be outside. For instance what I might call " natural wickedness " gets off very lightly. 
By natural wickedness I mean the things we all would like to do but are scared to and therefore pretend that we wouldn't " lower ourselves" to do. That includes violent language, hitting our neighbours, being in a filthy condition, staying in bed all day, gambling all night, stripping our neighbours' fruit trees and libellous defamation of character. Anything from an hour to "satu hari lock-up " suffices for these.

On the other hand disrespect to any of the staff would be judged an extremely serious offence. Back chat to the Medical Superintendent for instance would probably get eighty to ninety years imprisonment according to the gravity of the offence.

The sentence passed on a prisoner is not, as in outside courts, the end of the case. It is merely the beginning, like the opening price suggested by the barang man when he sold you that brass tray. It goes very much like this :-

Magistrate: "Ada salah, tiga hari lock-up."

Patient: "Tuan banyak bagus, satu halli chukop."

Magistrate: "Well, I'll make it dua hari."

Patient: "Tuan numba satu punya-Kasi satu halli."

Magistrate: "Certainly not. Jangan chakop bohong. Misti kena dua hari."

Patient: (loud wailing)-Too-aaan!"

Magistrate: (hastily)_All right. Satu hari be it."

It is not a bad system really. After all the prisoner is the interested party and should have some say in his sentence.

To take an example of justice in Sungei Buloh. I come down in the morning to be greeted by the clerk.

Clerk: Good morning, Sir. Sir, there was some frackass in the Settlement last night.

Self: Some what?

Clerk: Some frackass, Sir.

Self: What the-Oh! I see. Well who's been fighting now.

Clerk: Ramasamy Two and Lazarus the Scavenger, Sir.

Ramasamy Two has a moving story to tell. He was cycling along peacefully and inoffensively when the scavenger suddenly rushed out at him, knocked him off the bike, struck him till he was unconscious and he was only saved 
by the timely intervention of his friends who pulled off the scavenger so that Ramasamy Two could run away. Throughout the whole attack he never attempted to hit back using only kind words begging Lazarus please to desist. Yes, just like that. He is backed up by three witnesses. Lazarus the Scavenger has an equally sad tale. He saw Ramasamy Two cycling along and saw him tumble from his cycle. Bursting like a mattress with brotherly love he rushed over to pick him up, dust him and send him happily on his way. Imagine his consternation when Ramasamy Two turned on his good Samaritan and hit him repeatedly with the clenched fist. He made no attempt to retaliate only begging Ramasamy Two to be merciful. It was just too bad. $\mathrm{He}$ also has three witnesses.

Having listened to these two schools of thought it comes to me that both must have a singularly low opinion of intelligence to hand out this kind of thing. I turn and reflect a moment on the witnesses.

As a rule I prefer to do justice without the bother of listening to witnesses, whom I find just tend to obscure the issue. Witnesses remind me frequently of the paragraph in front of novels stating that all events narrated herein are wholly imaginary and have no relation to any living person. In fact it would save a lot of trouble if this statement were elicited by the court interpreter instead of the usual oath.

Meanwhile Ramasamy Two has thought up something new, having noticed that the Tuan is evidently insufficiently impressed. The assailant-Lazarus the Scavenger-not only attacked him but used a very Wicked Word. He peers anxiously, wondering how that goes down.

"What word?" I ask.

After a flood of interpretations I am informed that the word is such that it could not be repeated in the Tuan's ears. This seems to leave me a trifle out of the party. I become faintly annoyed.

"All the witnesses go to prison for an hour."

The policemen assume that look of alert self-righteousness that all police appear to affect when dealing with a prisoner, and trundle off the loudly protesting witnesses. That gets rid of six Tamils and two policemen. One feels that the general atmosphere of tutored untruthfulness has cleared considerably.

The two principals Ramasamy Two and Lazarus the Scavenger remain. I look at them, sullen, torpid and disgruntled like everybody, except the end man in "Who's been 
at my Eno's." This reflection plus a closer look arouses certain ideas that are more medical than judicial. "Enquire," I say to the clerk, " enquire as to whether these two men are in need of Eno's." (These are not perhaps my exact words at the time). The enquiry is made, ruthlessly, publicly and with a refreshing lack of delicacy. Alas, it is only too true. Both Ramasamy Two and Lazarus the Scavenger stand in painful and self-admitted need of Eno's. Now emerges the reason for the bad temper, the sullenness and the quarelling. Decision is easy.

"Both are to have four ounces of white mixture and have it right now."

The sentence is carried out amid the loud approval of the audience who appear to think the decision a happy one. The Sergeant unbends so far as to felicitate me in my judgment. I am unaware of having asked his opinion but I cannot but concede my concurrence.

"As a matter of fact looking round the spectators there are quite a few who could do with the same . . . ." the court clears with remarkable celerity proving that my words are clearly audible.

In a couple of minutes I am left alone with the clerk. "Well, that's justice done for today." "Yes, Sir " says the clerk. "Er, just a minute before you go, clerk."

"Yes, Sir."

"It really doesn't matter particularly-just as a matter of interest-er-ah-Just what was that word that was so bad it couldn't be repeated in my ear?"

I suppose it comes to most of us, this wretched duty of being nasty to some particular person for his own and everybody else's good. When the prisoner is your own patient it is worse than ever. In the case of a leper-one who has suffered more than you and I will ever be called on to suffer -it is doubly and trebly difficult. I once heard it said that before passing a sentence one should ask oneself three questions-“"Is it just?"- "Is it kind?"- "Is it necessary?"

I would like to add one more of my own and to suggest to those of you who from time to time have to "tangkap " a leper to send him to Sungei Buloh. "Can you understand what he has been through?" 